IBAD Sosyal Bilimler Dergisi

IBAD Journal of Social Sciences

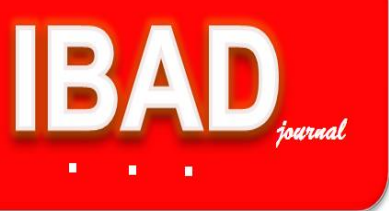

IBAD, 2019; (Özel Sayı): 38-52

DOI: $10.21733 /$ ibad.603536

Derleme / Review Article

\title{
Barbara Kruger’in Tasarımlarını Göstergelerarasılığın Yeniden Üretim Yöntemleriyle Okumak
}

\section{Dr. Öğretim Üyesi Dilek Çulha ${ }^{{ }^{*}}$}

Geliș tarihi: 08/08/2019

Kabul tarihi: 22/08/2019

\section{Atıf bilgisi:}

IBAD Sosyal Bilimler Dergisi

Sayı: Özel Sayı Sayfa: $38-52$

Yıl: 2019

This article was checked by Turnitin. Similarity Index 8\%

1 Yalova Üniversitesi, Sanat ve Tasarım Fakültesi, Grafik Tasarımı Bölümü Yalova/ Türkiye.

dileki.culha@gmail.com

ORCID ID 0000-0000-3077-8943

\footnotetext{
* Sorumlu yazar
}

ÖZ

Postmodern dönem, toplumun çeşitli alanlarındaki değişim ve dönüşümünü anlamlandıran kavram ve teorilerin eşliğinde tanımlanmaktadır. Bu eklektik yapıyı kuran yazın alanında metinlerarasılık ve görsel alanda göstergelerarasılığın içeriğinde irdelenen yeniden üretim modelleridir. Yeniden üretim; parodi (yansıma) ve pastiş (öykünme) gibi kavramlarla geçmiş ve gelecek arasında varlık gösteren yazının, söylemin ve görselin günün koșullarına dönüșümünün bașka bir okumas olarak ele alınabilinir. Bu görüşü görsel sanatlar içinde tasarımlarına yansıtan isim Barbara Kruger'dir. Onun çift dille kodladığı eleştirel nitelikli tasarımları daha çok toplumsal bilinen bir bilgiyi kuran ataerkil yapının inşa ettiği, toplumsal gerçekliğin rolünü eleştirebilir kılmaktadır. Böyle bir okumanın amacı; grafik tasarımda fikir çözümlemesine düşünsel kuramlar ile yaklaşılabileceğine işaret etmektedir. Çünkü kuram, toplumsal yapının oluşturduğu bilgileri dönemin düşünsel koşullar doğrultusunda değișiminin sorgusunu açığa çıkarmaktadır. Bu bağlamda Kruger'in tasarımlarını kuram ile okumak; parodi ve pastişin açıklanmasını sağlarken, grafik dilinin zihinsel etkisinin anlaşılmasına yardımcı olması bakımından da önemlidir.

Anahtar Kelimeler: Barbara Kruger, Afiş Tasarımı, Yeniden Üretim, Disiplinleraras1. 


\title{
Reading Barbara Kruger's Designs Using Reproduction Methods of Intersemiotics Perspective
}

\author{
Assist. Prof. Dr. Dilek Çulha ${ }^{1}$
}

First received: 08/08/2019 Accepted: 22/08/2019

\section{Citation:}

IBAD Journal of Social Sciences Issue: Special Issue Pages: $38-52$ Year: 2019

This article was checked by Turnitin. Similarity Index 8\%

'Yalova University, Faculty of Art and Design, Graphic Design Department Yalova/ Turkey.

dilek.i.culha@gmail.com

ORCID ID 0000-0000-3077-8943

\section{* Corresponding Author}

\begin{abstract}
The postmodern era is defined by the concepts and theories that make sense of change and transformation in various fields of society. This eclectic structure is formed by the models of reproduction, which are examined in the context of intertextuality in the field of literature and intersemiotics in the visual field. Reproduction can be considered as another view of the transformation of writing, discourse and visual field, which have been existing with concepts like parody (reflection) and pastiche (emulation) between the past and the future, into the conditions of the day. Barbara Kruger reflects this idea in her designs in visual arts. Her bilingual critical designs make it more possible to criticize the role of the social reality which is constructed by the patriarchal structure that builds socially known knowledge. The purpose of such a reading is to point out that the idea analysis in graphic design can be approached through intellectual theories. This is because the theory means revealing the interrogation of the change of the information formed by the social structure in accordance with the intellectual conditions of the period. In this context, reading Kruger's designs through theory is important in explaining parody and pastiche, while also helping understand the mental impact of graphic language.
\end{abstract}

Keywords: Barbara Kruger, Poster Design, Reproduction, Interdisciplinarity. 


\section{GíRiș}

Postmodernist dönemde; hayat, sanat, tasarım, reklamcılık gibi disiplinlerarası alışverişin yaşandığı bir düşünsel ağ yaratılmış ve kuramlarla tartışılmıştır. Bu kuramlar daha çok yazın alanında sözsel; görsel alanda ise sözel olmayan sanatlar olarak ayrılmaktadır. $\mathrm{Bu}$ ayrım, metinlerarasılığın yanı sıra göstergelerarasılık kavramını da beraberinde getirmiştir. Metinlerarasılık, yazın alanındaki metinlerin birbiri ile ilişkisi üzerinden açıklanırken; göstergelerarasılık tanımı, "Roman Jocobson'un bir çeviri biçimleri üzerinden irdelediği '(...) dilsel göstergelerin dilsel olmayan gösterge dizgeleri aracıllğıyla yorumuna" (Aktulum, 2011, s. 17) dayanmaktadır. Bu bağlamda dönemin kavramlarını açıklama çabaları; bir metnin kendi kendine anlamlı bir yapı olarak algılanmasından çok, başka bir metinlesözceyle-görüntüyle veyahut disiplinle ilişkilendirildiğinde ortaya çıkan algıya bağlı olduğu söylenebilir. Postyapısalcıların belli kuralları ve dizgeleri yıkıp sadece sanata ve malzemenin "ne" liğine yönelmesi, sanatın tanımlarının genişlemesine vesile olması burada önem kazanır. Artık "sanat yapıtı açık bir yapıda olduğuna göre, malzemesini diğer sanat biçimlerinden, disiplinlerden, türlerden tüketerek, kendi içerisinde ötekilere sürekli olarak göndermeler yaparak ya da onları alıntılayarak bu açıklığı yaratabilecektir" (Aktulum, 2011, s. 366). Bu düşünce ile meseleye bakıldığında metinlerarasılığı kapsayan yazın sanatlarının kuramlarını, göstergelerarasılık adı altında görsel sanatlarda okumak eylemi normalleşmiştir denebilir. Böyle bir okuma sanatın, tasarımın ve birçok ortak disiplinin yapılanmasına ivme kazandırmıştır.

$\mathrm{Bu}$ yaklaşım modeli sanat ve tasarımı aynı potada eriten, reklamcı Barbara Kruger'in tasarımlarını akla getirmektedir. Reklam, Kruger' in sanat ve tasarımda çözümcü bir fikir etrafında uygulamalar yapmasını sağlayan alandır. Bu nedenle Kruger'in, Mademoiselle ve House and Garden dergilerinde sanat yönetmeni asistanlı̆̆ 1 sürecindeki deneyimleri ve tasarımcı bakış açısı, toplumsal kültürün açmazlarını sorgulayacak eleştirel bir dil geliştirmesine olanak tanımaktadır. Kruger'in 1970-1980 yılları arasındaki "öteki”, "güç", "iktidar", "Irk", "beden" ve "cinsiyet" gibi kavramlar ile irdelediği tasarımları, kadına yönelik yaratılmış toplumsal dilin düşünsel tavrını açığa çıkarmaktadır. 1970'li yıllardan günümüze değin kadınların rolü ve toplumsal haklarının sorgusu, çeşitli teorilerin ve pratiklerin gelişmesi içerisinde açımlanmaktadır. Bu bağlamda modern dönemden postmodern döneme geçişte söylemlerin işleyişi ve özellikle kadın tanımlarının tüketim kavramları ile yan yana getirilmesi, reklamın ana malzemesi hâline dönüşmüştür. Kruger de tasarımlarında, özellikle reklamın yaygınlaştırdığı moda dergilerinin en bilindik görüntüleri ile çift dilli kodladığ 1 sloganları bir arada kurgulayarak toplum içerisindeki erk düzenin söylemini görünür kılmaktadır. Bilinen görüntülerin kullanılması postmodern dönemin yeniden üretim tanımları içerisinde açıklanabilmektedir. Her şeyden önce yeniden üretim; metinlerarasılık ve göstergelerarasılık kavramlarının temel özelliği olan parodi (yansılama) ve pastiş (öykünme) yöntemleri içerisinde incelenmektedir. Tüm bu yeniden üretim yöntemleri Kruger'in tasarımlarında kurduğu güçlü dil oyunlarının alt metnini okumamamıza yardımcı olmaktadır. Kruger hem sanat hem de tasarım yönü kuvvetli bir üreticidir, o tasarımlarını sadece çağdaş sanat sergi mekânlarında, müzelerde konumlandırmamış; aynı zamanda tüketim alanlarının mecrasına dönüşen afiş ve billboardlarla kamusal alanlarda sergilemiştir.

\section{Metinlerarasısık, Göstergelerarasılık Tanımları İçeriğinde Yeniden Üretim Yöntemleri}

Postmodernizmin içinde gelişen, metin ve felsefe alanlarında tartışlan yeniden üretim modelleri ve tanımları, her şeyin daha önceden söylenmiş olma düşüncesi üzerine kuruludur. $\mathrm{Bu}$ durum birçok disiplinde yöntembilim olarak ele alınmakta ve bitmeyen sonsuz okumaların önünü açmaktadır. Denebilir ki postmodernizm argümanları, modern dönem yazılarının farklı biçem ve tarzlarla yeniden okunmasına-yazılmasına olanak tanıyan metinler toplamından meydana gelmektedir. Birçok metnin bilgisini teknik ve yöntem olarak inceleyen Julia Kristeva'nın yazınsal çözümleme aşamalarını ulaştı̆̆ "metinlerarasılık" in genel tanımına göre, "her metin kendisini alıntıların mozaiği olarak inşa eder ve her metin, bir başka metnin kendisine katılması ve dönüştürülmesidir" (Rose, 2016, s. 237). Bu nedenle metinlerarasılık düşüncesinde metin, kendi içerisinde değil; diğer metinlerle kurulan ilişkilerle yeniden değerlendirilir. Başka bir deyişle metinlerarasılık tanımlarında bir metin diğer metinlerden bağımsız olarak varlık gösteremediğinden, her metin bir metinlerarasılık niteliği taşımaktadır. Her metnin daha 
önce yazılmış metinlerle bağlantılı olması durumu, metne "alıntısal" olma özelliği katmakta ve yöntem biçimlerinin önünü açmaktadır. Ancak yazın dışında kalan görsel sanatları kapsayacak olan alıntılama yöntemlerini açıklamak için, göstergelerarasılık kavramı tercih edilmektedir. Bu göstergelerarasılık açılımlarında varlık gösteren alıntılama yönteminin esası Aktulum'un aktarımıyla şöyle açıklanabilir.

Göstergelerarasılık, bir sanat biçiminin (sözel bir sanat, örneğin roman) başka bir sanat biçimindeki (sözsel-olmayan sanat, örneğin müzik, resim) varlığı yanında türleri, farklı biçemler arası alışverişleri göstermek için de kullanılır; özgül olarak ayrışıklık yaratan bir biçemin, türün (resimsel ya da müziksel biçem) başka bir biçem ya da türde nasıl işlediği sorusuna yanıt aranırken göstergelerarasılık sürecine girilir (Aktulum, 2011, s. 19).

Metinlerarasılıkta yöntem olarak adlandırılan; parodi (yansılama) ve pastiş (öykünme) gibi yeniden üretim teknikleri, göstergelerarasılık kavramın temelinde de bir dönüştürüm aracı olarak "alıntı" açılımıyla yer almaktadır. Alıntı; genel itibariyle bilinen bir bilgiden-görselden-kişiden bilinçli yapılan bir atıfta bulunma eylemidir. Denebilir ki hem metinlerarasılı̆̆ 1 hem de göstergelerarasılığın açığa çıaran temel sav; alıntı sözcügüdür ve bu sözcük, tüm yeniden üretim tekniklerinin ana malzemesidir.

Alıntı devingendir; görevi ise eski bilgileri harekete geçirmek, yazınsal ya da resimsel bir mirası, bilgiyi yeniden güncellemektir. [...] Alıntı yalın bir yineleme işlevi değil, Compagnon'un söylediği gibi bir yeniden sözceleme edimidir: Aktarılan kesit yeni bir bağlama sokulur, onu anlamsal olarak dönüştürür. Dönüştürürken kendisi de kimi dönüşümlere uğrar; biçimsel bir dönüşüm değildir bu, daha çok anlamsal ve bağlamsal bir dönüşümdür. Yazılı/sözsel dilde alıntılayan ve alıntılanan söylemler aynı göstergebilimsel yapıdadırlar; oysa alıntının iki unsuru arasındaki biçimsel uyum resimde zorunlu değildir. Alıntının kaynağı görsel olmayabilir. Bir resim bir başka resmi, gravürü, fotoğrafı alıntılayabilir, ancak bir şiiri (...) sözleri ya da müzik parçasını da (...) alıntılayabilir. Bir metin görüntüleri betimleyerek, renkleri, biçimleri, oranları söze dökerek alıntılar. Bir resme, resmin başlığına gönderme yaptığında her şeyi dile dönüştürür. Gönderme, anıştırma, eğretileme vb. kullanımlar görüntüleri söze dökerken yoğun olarak kullanılırlar. Alıntı iki yapıt arasında olası bir ilişki kurar, alıntılayan yapıt alıntılanan yapıtı özgün bir biçimde alıntılar, onu yeni bir bağlamda yeni bir anlamla donatır (Aktulum, 2011, s. 44-45).

Her ne kadar alıntı tanımları daha çok yazın alanında ele alınmış olsa da postmodernizmle birlikte görsel sanatlar gibi (disiplinlerarası etkileşimin artması ve bilgilerin kaynaşmasından dolayı), yazın olmayan sanatları da kapsamaktadır. Alıntılama tekniklerinden biri olan Parodi (yansılama), var olan bir anlamın/yazının/görselin yeniden üretilmesi olarak tanımlanabilir. Güncel Türkçe Sözlük tanımında parodi, "Ciddi sayllan bir eserin bir bölümü veya bütününü alaya alarak, biçimini bozmadan ona bambaşka bir özellik vererek, biçimle öz arasındaki bu ayrılıktan gülünç etki yaratan bir oyun türü” (http://sozluk.gov.tr) olarak açıklanmaktadır. Parodi özellikle 20. yüzyılda ortaya çıkan modernitenin yeniden okunması olan postmodernizm dönemde, komik ve gülünç olma özelliğinin yerine, bir yöntem biçimi olarak irdelenmektedir. Parodinin en belirgin yaygın kullanımı aslında izleyiciyi, farkındalık yaratacak düşünsel süreçle karşı karşıya getirmesidir. Bu nedenle grafik tasarımda parodi “... görsel bir kelime oyununa veya başka tür bir grafik nükteye dönüştürme eylemi” (Steven Heller, 2016, s. 134) olarak açıklanmaktadır. Görsel sanatlarda bir görselin yeniden üretilmesi parodiden çok, pastiş yöntemiyle anılmaktadır. Pastiş 'in (öykünme), göstergelerarasılık içerisinde öykünmenin ötesinde olduğu düşünülür; bir taklit, temellük etme kavramı ile yan yana getirilmektedir. En genel tanımıyla pastiş; çeşitli eserlerden alınan parçaların, bir bütün içinde eritilmeden veya özgün bir çalışma oluşturmadan, bir yapıt oluşturmak amacıyla yeniden düzenlenmesi olarak tanımlanabilir. Postmodernizm ile bir taklit olarak da görülen pastiş, temellük, diğer adıyla kendine mal etme sanatı, orijinallik açılımlarıyla sahiplik kavramını sorguya açmaktadır. Pastiş daha çok tarafsız bir taklit faaliyeti olarak sanat yapıtlarında varlık göstermektedir. Taklit (imitation) parodik türlerin ana tekniklerinden biridir ve genel itibariyle bir yapıtın-düşüncenin-görselin yeniden üretilmesi üzerinden gerçekleşmektedir. Bu bağlamda taklit hem orijinal metnin-eserin algılanmasını sağlarken, hem de karşıt bir düşünce yaratılmasını da sağlayacak en önemli faktördür. Taklitle ortaya çıkan zaman değişimleri 
içerisinde anlamın dönüşümüdür. Bu nedenle, parodi (yansılama) ve pastiş (öykünme) tarihselliğin yeniden okunması olarak ele alındığında, Jameson'ın tarihe dönüş ile bireyi ele alış düşüncesi burada önem kazanır. Jameson postmodern bireyi Lacan'ın şizofren kavramı üzerinden açıklamakta ve şizofren bireyin vurgusunu, geçmiş ve şimdi arasındaki zaman geçişlerinde kaybolması olarak ele almaktadır. Ona göre; “(...) Şizofren 'hiç kimse'dir, hiçbir kişisel kimliği yoktur. Dahası şizofrenin belli bir zamansal süreklilik içerisinde kendisini adayabileceği hiçbir tasarısı da yoktur. Kısacası şizofren birbirine eklenen şimdilerden oluşan bir bölük pörçüklük doğrultusunda deneyimler zamanı" (Sarup, 2010, s. 207). Jameson; postmodern bireyin bu "geçmişi bilememe" halini ve tarihselliğin yeniden üretilmesi durumunun pastiş kavramın yaratılmasına yol açtığını ifade eder. Parodi ve pastiş arasındaki ayrım, Frederic Jameson alıntılanarak şöyle açıklanabilir:

Parodi gibi pastiş de özel ya da eşsiz bir biçime öykünme, biçemsel bir maskenin takılması, ölü bir dil içinde konuşmadır: Fakat pastiş, parodinin gizli niyeti, şeytani itkisi, kahkahası ve öykünülen şeyin oldukça komik olmasıyla kıyaslandığında normal bir şey olarak var olduğuna ilişkin gizli duygusu bulunmayan bir tür yansız taklitçilik pratiğidir. Pastiş, boş, mizahi anlamını yitirmiş bir parodidir (Jameson, 2005, s. 17).

Bu iki alıntılama tekniği, 'ready-made' (hazır yapım) ürünlerin sanatın nesnesi olarak kullanılmasıla birlikte görsel sanatların yöntemi olarak anılmaya başlamıştır. Parodi ve pastiş uygulamalarının ortak tavr1, orijinal el üretimi eserlerini ve yaratıcısı olarak sanatçıyı sorguya açan Avandgard dönemin başlangıcına işaret ederken, düşünsel bir yapının yayılmasında da etkin rol üstlenmektedir. Çünkü parodi ve pastişin, kurgulanmış düşüncenin sahiplenilerek yeniden üretilmesi, yeniden kurgulaması, hâlihazırda var olan anlamlandırmaların yeniden sorgulaması için zemin oluşturması gibi bir niyeti vardır. $\mathrm{Bu}$ düşüncenin etkisi Benjamin'in tanımladığı yeniden üretim tekniğinin okunması ile daha net anlaşılabilir.

Yeniden üretim tekniği, yeniden-üretilmiş olanı geleneğin alanından koparıp almaktadır. $\mathrm{Bu}$ yeniden-üretilmişi çoğaltarak, onun bir defaya özgü varlı̆̆ının yerine, yine onun bu kez kitlesel varlığını geçirmektedir. Ve yeniden-üretilmiş olanın, alımlayıcıya bulunduğu konumda seslenmesine izin vermekle, üretilmiş olanı güncelleştirmektedir (Benjamin, 2012, s. 55).

Kuramlar, bir yazın ile görselin, bir görsel ile sözcenin yer değiştirerek yeni anlamlar eklemlenmesini sağlamaktadır. Yani dönemin herhangi bir zamanında söylenmiş bir söylem, günün koşullarındaki söylemi ya doğrular ya da tersinler nitelikte başka bir söyleme dönüştürebilmektedir. $\mathrm{Bu}$ durum, gösterilen gerçeğin düşünsel olarak eleştirisini yapabilme halini alır. Belki de bu yöntemin amacı; görünen ile gerçek arasındaki gerilimde kişinin ne gördüğü, toplumsal gösterilen gerçeğin ne olduğu ve aslında ne olması gerektiği sorgusunu açığa çıkarmaktır. Çünkü bu yazın ve "sözce" ye ait dönüşümün tanımları, günümüz dünyasında varlık gösteren görüntü, afiş, resim, film, metin vs. gibi sanat ve tasarımın birçok alanındaki düşünsel dönüşümü de kapsamaktadır. Bu disiplinlerin iç içe geçmiş anlamlandırma çabaları, grafik tasarımcı olan Barbara Kruger'in görsel ve söylem arasında çifte dil yaratarak ürettiği afiş tasarımlarını, yeniden üretim yöntemleriyle okumayı olanaklı kılmaktadır.

\section{Yeniden Üretim Yöntemleri İle Barbara Kruger'in Grafik Dilini Okumak}

Barbara Kruger'in tasarımlarının yönü çift kodlanmış bir düşüncenin geçmişteki ve şimdideki duruşlarını açığa çıkartmaktadır. O tasarımlarının düşüncesini, ataerkil söylemin arzusu üzerine inşa edilmiş toplumsal bilgiyi hedef alacak şekilde konumlandırmaktadır. Bu nedenle onun tasarımlarında kadınlık göstergeleri ile tüketimin arasındaki ilişkiyi nasıl kurduğunun sorgusuna rastlamak mümkündür. $\mathrm{Bu}$ bağlamda Kruger tasarımlarındaki grafik dilini, bilinen görsel ya da söylemsel gerçeklik üzerine oturtmuştur denebilir. Bu bilinen bilgi, dolaşıma yeniden üretim yöntemleriyle sokulmaktadır. Çünkü kadınlık ve erkeklik söylemlerinin arzusu, insanoğlu var olduğu sürece yinelenmektedir. Bu yinelemede bir önceki bilginin varlığına atıfta bulunulmaktadır. Bu nedenle Deleuze ve Guattari’nin savunduğu gibi bastırılmış bilinçdışı olarak da algılanabilecek arzu söylemi, burada önem kazanır. Arzu, yazın-söylem ve görsel sanatlar gibi tüm alanlara yayılmakta ve söylemin gerçeklikle ilişkinin sorgulamasına aracı olmaktadır. Ahu Antmen'in Kruger'in tasarımlarına yönelik açıklaması da bu düşünceyi destekler niteliktedir. 
Kruger kitle iletişim araçlarının yaymakta olduğu popular kültürün cinsiyet ayırımcı tavrını yapısöküme uğratmayı amaçlamıştır. Dergilerden, takvimlerden, sağlık/güzellik rehberlerinden seçtiği hazır-imgeleri bunlardan yansıyan mesajlar yerine kendi saptadığ mesajlarla tekrar dolaşıma sokan Kruger, toplumda özellikle kadınların arzularını şekillendiren söylemleri açığa çıkarmayı amaçlamıştır (Antmen, 2010, s. 279).

Barbara Kruger'in temelde yaptığı, reklam dilinin tüketim algısına vurgu yapan sıradan olan görseller ile toplumun kadın için ürettiği söylemlerin alt metnini ilişkilendirmektir. Bu da moda sektörüne ait bilinen görseller ile yeniden dolaşıma giren güncel söylemlerin ilintilenmesi ile açığa çıkmaktadır. Bunun içinde Kruger grafik tasarımın görüntü, tipografi ve renk gibi tasarım elemanlarını statik bir biçimde düzenlemektedir. Tasarımlarının anlamsal boyutu ise ironik bir şekilde devingendir. Kruger'in afiş tasarımları, toplumsal içerisinde ataerkilin kurduğu gerçekliği, yeniden üreterek dolaşıma soktuğu için parodi ve pastiş yöntemleriyle okunabilmektedir. Kruger'in isimsiz adlı afişs serisinin bütününde de yaptığı, görüntünün söylediği ile sloganın söylediği arasındaki gerilimi görünür kılmaktır. Bu tutum parodi açılımlarında rastlanan "çift kodlanma" tanımlarıyla benzerlik göstermektedir. Çift kodlama terimi:

Charles Jencks tarafından postmodernin tanımlayıcı olarak kullanılması ve terimin diğer bazı kuramcılar tarafindan "postmodern" metinlerarasılık ve parodi kavramlarını kapsayacak şekilde kullanılmasına istinaden, (...) Lachmann, 'çiftkodlama'nın, [Doppelkodierung] anlam oluşturma işinin, verili metindeki mevcut işaret miktarı aracıllğıyla değil diğer metindeki işaretler aracılığıyla programlandığı anlamına geldiğini” ileri sürerken "çift kodlama" kavramından Bahthin'in üslupsal parodi tanımlarını hatırlatması açısından bir tür metinlerarasll1k olarak bahsetmeye devam eder (Rose, 2016, s. 244).

Parodi içeriğindeki çift kodlama; metnin (görselin veyahut sloganın) kendinden olan bir anlamın yanına; çelişkili, -mış gibi veya destekler nitelikte başka bir anlamın eklenmesiyle ortaya çıkmaktadır. Çift kodlama dilsel bir yapıdadır. Dil ise toplumsal yaşam içerisinde söylemleri kurmakta ve toplumsal bilinen doğruları temsil etmektedir. Bu nedenle Kruger'in afişleri, çift kodlanmış dil üzerinden verili bilginin anlamını deştiği sloganları ile güçlü imajların birlikteliğinden oluşmaktadır. Bu da demektir ki Kruger, tasarımlarındaki çifte kodlama ile dönemin söylemi olan kadın ve kadına yapışmış tüm kavramları, tüketimi ve üretimi kapsayacak şekilde irdelemektedir. Bu çifte kodlama kapitalist modelin kurduğu tek tipleştirmeye karşı bir tavırdır da aslında. "Metinlerarasılık" taki parodideki çift kodlama anlam odaklı olduğu için; yazarın, tasarımcının ya da sanatçının parodici olma özelliğini de ortaya çıkartmaktadır.

... metinler arasındaki zıtlık kadar metnin bütünleşmesi de parodist programın bir parçasıdır, iki kod kullanma tercihinin parodiciye ait olduğunu ve sonuçta ortaya çıkan parodi metnin (ya da verilen metnin) kendisi içine yerleştirilen başka bir metnin varlığına işaret edebilecekken sonuçta ortaya çıkan parodi metnin içine yerleştirilen metni yeniden yorumlayan ve ona parodi metnin tümü içinde yeni işlevler ve imalar yükleyenin parodici olduğunu kanıtlar (Rose, 2016, s. 244).

Bir tasarımcıyı parodici olarak tanımlanmasını sağlayacak en önemli etmen, yaptığı tasarımda arzu olarak neyi anlamlandırmak istediğidir. Deleuze ve Guattari'nin temel odağı olan "arzu" kavramı, 1970'li yıllardaki yayınlarında daha çok arzu politikaları ismiyle geniş bir şekilde irdelenmiş̧ir. Onların düşüncesinde arzu ve arzu felsefesi genel tanımı şöyledir.

"arzu çeşitli fark katmanlarının farklılaşması sayesinde ortaya çıkar: (...) "Fikirleri biçimlendiren ve birleştiren farklar; duyguları ve kuvvetleri ifade eden farklar; kuvvetleri edimsel bedenler halinde birleştiren farklar ve bir varlığın ortaya çıkışında ve kendisini çoğaltmasında örtük olarak bulunan farklar. Arzunun bütünlüğüne ancak bu düşünce, duygu, beden ve ontoloji katmanları birbirleriyle etkileşime girdiğinde ulaşılır" (Goodchild, 1996, s. $31)$. 
$\mathrm{Bu}$ durum, toplum içindeki bilginin arzu modellerini anlaşılır kılmaktadır. Deleuze ve Guattari'nin, arzuyu kuramla ve bilgi üzerinden toplumsal bilinç-bilinçdışı olarak tanımlaması, anlamı tekillikten kurtarmayla ilişkilidir.

(...) arzu, toplumsal bilinçdışıdır: Arzu, bilinci oluşturur ve koşullandırır, öyle ki sonunda imgeler sadece, kişinin içine gömüldüğü toplumsal ilişkilerin ürünleri haline gelir. Bu anlayış, düşünce üretiminin koşullarıyla ilgili aşkın bir felsefe; toplumu oluşturan içkin ilişsilerle ilgili toplumsal bir kuram; toplumun, o topluma ait toplumsal bilinçdışının dönüştürülmesi yoluyla dönüştürülmesiyle ilişkili bir arzu politikası arasında bir karşılaşmaya yol açar (Goodchild, 1996, s. 19).

Karşılaşmalar fikri, sorgulama fikrini de beraberinde getirmektedir. Sorgulama, Kruger'in tasarımlarındaki toplumsalın kurduğu arzunun yönünü dönüştürerek, kadının arzusuna çevirdiği isimsiz seri afişlerinde daha çok görülmektedir. Bu seride Kruger, kod, söylem, slogan, görüntü, renk gibi tasarımın elemanları ile bilgiyi bir arada düzenleyerek, izleyicinin yeni anlam karşılaşmalarına izin vermektedir.

\subsection{Barbara Kruger'in İsimsiz Afiş Serisi}

Barbara Kruger'in İsimsiz olarak tasarladığ 1 afiş serisi, yeniden üretim teknikleriyle açımlanabilecek niteliklere sahiptir. Bu tasarımların teknik olarak en temel özellikleri, hepsinin kırmızı bir çerçeve ile sınırlanması, beyaz yazı ile düzenlenmesi ve siyah-beyaz fotoğraflar ile güçlü sloganların bir arada harmanlaması olarak açıklanabilir. Sloganlar dönemin reklam anlayışında sıcça kullanılan Sans Serif Futura Bold Oblique yazı karakteri ile yazılmıştır. Reklam düşüncesinin birçok alanında kullanılan bu font, süslemecilikten uzak daha çok geometrik yapısıyla basit bir forma sahiptir. Bauhaus dönemi formlarını üzerinde taşıyan "Futura, ilk defa 1927 yılında Paul Renner tarafindan kullanılmaya başlandı. 1928 y1lında Light, Medium, Bold ve Bold Oblique fontlarından sonra, 1930 yılında Light Oblique, Medium Oblique, Demibold ve Demibold Oblique yazı karakterlerinin sunulmasıly font ailesi hizlıca gelişti. 1932 yılında Book, 1939 yılında Book Oblique ve 1952 yılında Edwin W. Shaar tarafindan hazırlanan Extra Bold yazı karakteri ile aileye eklemeler" (www.sanagrafi.com.2012) yapılarak font ailesi genişletilmiş ve reklam sektörünün en çok aranan fontu haline dönüşmüştür. Kırmızı çerçeveler hem dönemin reklam anlayışını hem de kadınlık ile ilişkilendirilen cazibe kavramını hatırlatır niteliktedir. Onun tasarımları çoğu zaman negatife karşı bir pozitif tavrın varlığına işaret etmektedir. Kruger'in tasarımlarında en belirgin özellik fotoğraf kullanımıdır. Fotoğraf, görüntülerin çoğaltılmasını ve hızlandırmasını sağlayan teknik bir araç görevini üstlenmektedir. Aynı zaman da fotoğraf kendine mal etme düşüncesinde, söylemin-görselin biriciklik yapısını sarsacak en yaygın kullanılan tekniktir. Bu da Kruger'in moda dergilerindeki hazır görsellerin kullanımının nedenini açıklamaktadır. Fotoğrafın yanı sıra baskı çeşitlerinin gelişimi ve montaj, fotomontaj gibi tekniklerin yaygınlaşması görüntünün oluşum tekniklerini çeşitlendirmiştir. Bu durumu irdeleyen Walter Benjamin, fotoğrafi sanatın aurasını kaybetmesinin nedenleri arasında göstermektedir. Çünkü Benjamin'e göre 'aura', sanat yapıtının "biriciklik' yapısını koruyan bir kavramdır. Teknik yolla yeniden üretilebilen yapıtların çoğaltılma niteliği sanatın bu, ‘biriciklik' ve ‘özgün yapıtların eşsizliği' tanımlarını zedelemektedir. Bu bağlamda sanatın 'aura'sını yıkan yeniden üretim teknikleri aynı zamanda, yaşanmış-yaşantılanan zamansal algıyı da değişime uğratmaktadır. Yeniden üretim tekniklerinin temel eleştirisi, toplumların dil düzleminde kurulan söylemsel pratiklerinin baskın olduğu dönemlerde daha çok belirmektedir. Bu söylemler gizli veyahut aleni olduğu zamanlarda serbestçe dolaşıma bulunduklarından kamusal alanda yaygınlaşmaktadır.

Sanatçının çalışmaları, kendi deyimiyle 'kimi temsil yöntemlerini tahrip etmek (bu temsildeki erkek egemenliğini) ve erkekler dünyasındaki kadın izleyicilerin yerlerini etkinleştirme girişimi olarak özetlenebilir. Kruger'in medyatik bilince dayalı işleri, kitle iletişimi, kitle kültürü ve yüksek sanat arasındaki kesişim noktasında konumlanmaktadır. Sanatçının çalışmaları, o güne dek geniş ölçüde erkek egemenliğine işaret eden 'orijinal'le yüzleşen, onu ajite eden ve kalıplaşan bu temsil yöntemlerini tahrip edici bir nitelik taşımaktadır”' (Şahiner, 2008, s. 198199). 
Yeniden üretim teknikleri, genel olarak bir bilgiye gönderme-atıfta bulunma niteliği taşır. Sadece metine değil, bir olaya, kişiye, karaktere yahut sosyal yaşam içerisinde bilinen bir yapıya-olguya-bilgiye yönelerek de gerçekleşebilmektedir. Metinlerarasıllğın tanımları içerisinden referansla başlayan ve sanat yapıtlarının hemen hemen tüm alanlarına yayılmış yöntem biçimlerinden olan parodi ve pastiş kavramları, tasarıma ya da yapıta yönelik okuma çokluğu yaratarak bitmemişlik duygusu vermekte ve yorum bilimin önünü açmaktadır.

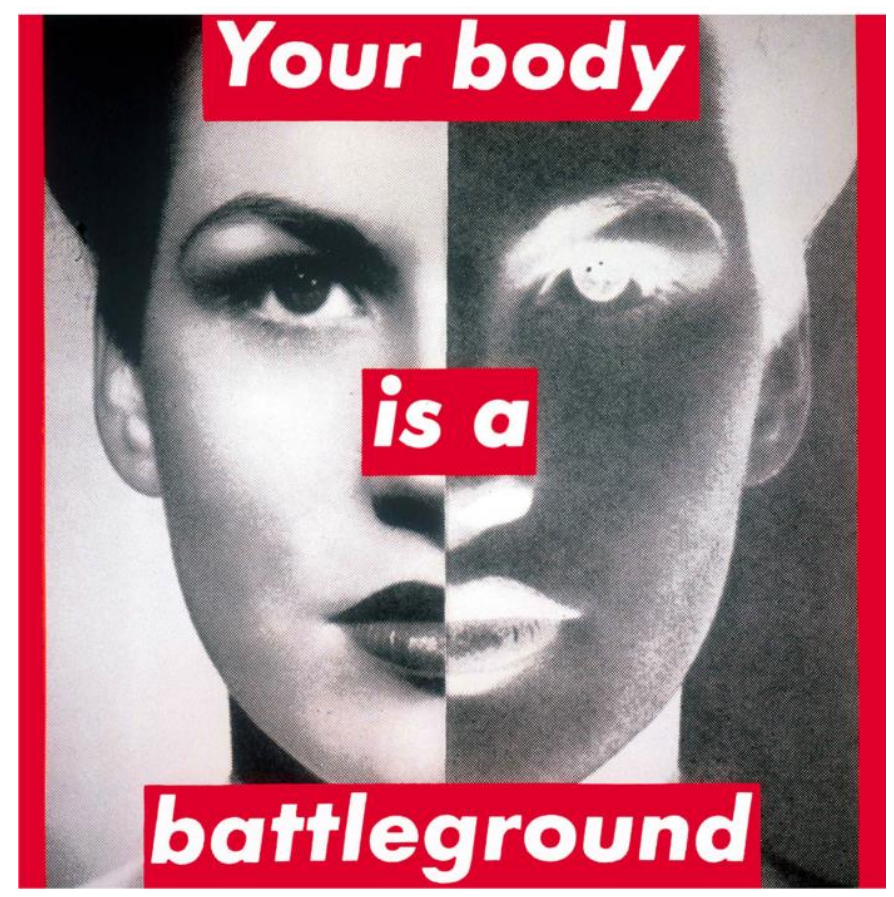

Şekil 1: Barbara Kruger, İsimsiz1990

Your body is a battleground,

(Bedeniniz bir savaş alanı).

(Caldwell, 2016).

Barbara Kruger'in İsimsiz serisinden Şekil 1: 'Your Body İs A Battleground' (Bedeniniz Bir Savaş Alını) olarak türkçeye çevrilen afiş tasarımında ilk dikkat çeken, kadının ve erkeğin yüzünün tam orta eksende negatif ve pozitif alan içerisinde ikiye bölünmesidir. Bu ayırım ile Kruger, "pozitife karş1 negatif, beyaza karşı siyah, iyiye karşı kötü” (Calak, 2008, s. 3) düşüncesi ile ikili bir ilişki kurmuştur. O tasarımındaki bu çifte kodu, kadına iyi (pozitif) ve erkeğe kötü(negatif) olarak yüklemektedir. Bu tasarım 1989 yılı kürtaj karşıtı yasa dalgasını protesto etmek için kullanılan bir tasarımdır. Afişs ile Kruger, slogan ile savaş alanı olarak nitelendirdiği kadın bedenini, kadınların kendini ispatın savaşı olarak algılatırken, erkeklerin o beden üzerindeki hâkimiyetini korumak için gerçekleştirdiği savaş olarak okunabilecek çifte bir dili açığa çıkarmakta ve tarihsel bilinen bir bilgiyi yinelemek için yeniden üretmektedir. $\mathrm{O}$ zaman denebilir ki; beden üzerine kurulan güç, erkeklerin kadınların vücutları üzerinde kurduğu güce işaret etmekte ve kendi bedeni için savaşma hakkını Kruger, kadına atfetmektedir. Kruger'in Satılık Aşk kitabından yola çıkarak, yaptığı açıklama şöyledir: "Güç merkezileştirilemez, bunun yerine dağıtılır, merkezsizleştirilir ve bunun sonucu olarak anonimdir: Sosyal vasıtaları ve kuruluşları birleștiren bir ilişkiler ağından daha az bir "beden" olarak mevcuttur (Calak, 2008, s. 3). 


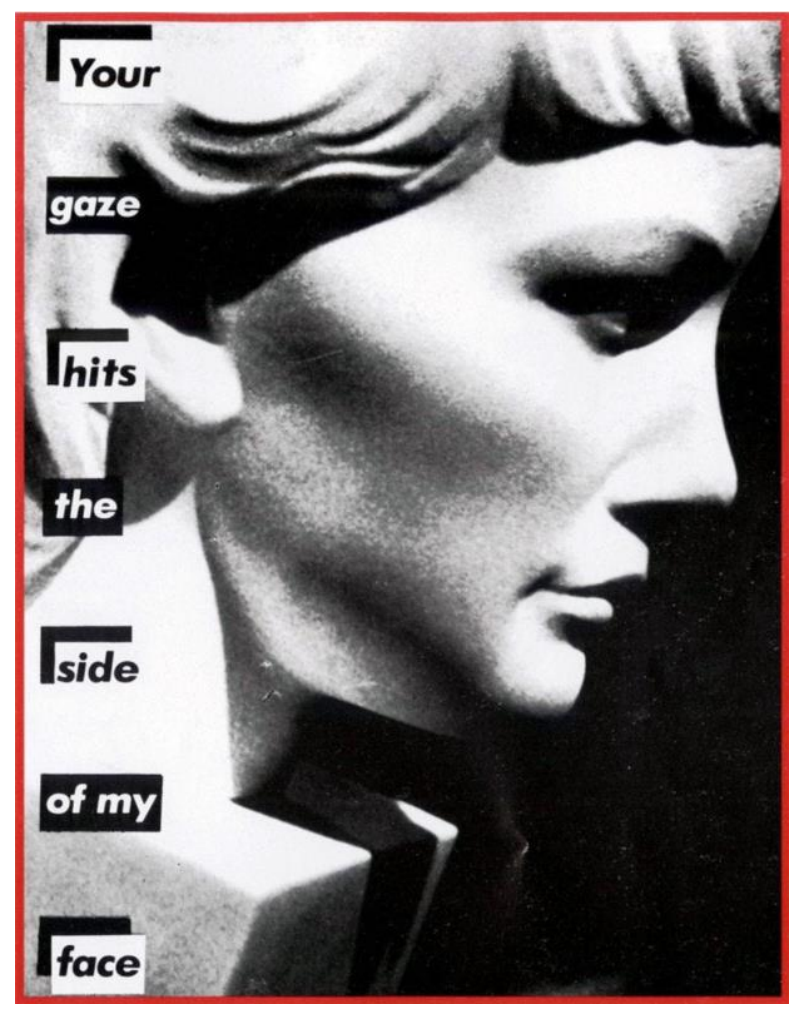

Şekil 2: Barbara Kruger, İsimsiz, 1981

Your gaze hits the side of my face

(Bakışın Yüzümün Yanına Vuruyor)

(Hedonia, A., 2019).

İsimsiz serisinden Şekil 2: Your Gaze Hits the Side of My Face. (Bakışın Yüzümün Yanına Vuruyor) adlı afiş, negatif ve pozitif sol bloğa yerleştirdiği slogan ile mekanik bir ifadenin olduğu kadın görselinin birlikte düzenlemesidir. Böylece bu afiş, doğrudan erkek bakışının kadına iliştirdiği bakılacak-görülecek nesne düşüncesinin bir yorumu olarak da okunabilmektedir. Linker' in tanımlarıyla okunduğunda afiş, "nesnesine tutuklu olmak - kelimenin tam anlamıyla taş kesmek - için bakışın gücüne atıfta bulunuyor olabilir" düşüncesine temellenmektedir (Çalak, 2008, s. 3). Kruger, kadın görselini tüm ifadelerden arındırmasına karşın, slogan ile erkeğin bakışını açığa vurmaktadır. Bu çifte kodlama, John Berger'in erkeğin, kadına bakışını açıkladığı metinle örtüşmektedir.

"Erkekler davrandıkları gibi, kadınlarsa göründükleri gibidirler. Erkekler kadınları seyrederler. Kadınlarsa seyredilişlerini seyrederler. Bu durum, yalnız erkekler ile kadınlar arasındaki ilişkileri değil, kadınların kendileriyle ilişkilerini de belirler. Kadının içindeki gözlemci erkek, gözlenense kadındır. Böylece kadın kendisini bir nesneye- özellikle görsel bir nesneye- seyirlik bir şeye dönüştürmüş olur (Berger, 1986, s. 47).

Kruger ise afişinde toplumun düşünsel ağına yayılmış bu görüşü desteklermiş gibi gözükürken, sloganıyla düşünsel ters bir dil üreterek izleyiciyi yüzleştirmektedir. Tasarımda slogan; erkeğin neyi görmek isteğini belirlerken, aynı zamanda kadına yüklenmiş gerçeğin ifadesini de üstlenmektedir. Parodi olarak irdelenebilecek bu durumda, görüntü ile kadına yıllardır yapışmış anlamın -sanki başka doğası yok-muş gibi kabul gören- düşüncesini yansıtıyor gibidir. Bu durum erk düşüncenin yaydığı bir tavır olmasına karşın kadının da kabullendiği bir tutumdur. 
Kadınları, varlığı (esse), algılanan-varlık (percipi) olan sembolik nesneler halinde oluşturulan eril tahakküm, onları daimî bir bedensel güvensizlik, hatta sembolik bağımlılık halinde tutmak gibi bir etkiye sahiptir: her şeyden önce başkalarının bakışı tarafından var edilir ve o bakış için var olurlar, yani sıcakkanlı, çekici ve el altındaki nesneler olarak. Onlardan 'kadınsı', yani güler yüzlü, sempatik, dikkatli, itaatkâr, ağırbaşl, ölçülü olmaları beklenir, hatta kendi kendilerini geri plana atmaları. 'Dişilik' isimlendirilen, gerçek ya da hayali eril beklentilere bir tür boyun eğmeden başka bir şey değildir çoklukla, özellikle de EGO'nun büyütülmesi konusunda. (....) Sonuç olarak, başkalarının (ve sadece erkeklerinde değil) bakışına yönelik bağımlılık ilişkisi, varoluşlarının yapıtaşı haline gelmeye başlar (Bourdieu, 2015, s. 87).

Toplumsal hayattaki düşünme modellerinin hemen hemen tümü, kadın ve erkek tanımlarını cinsiyetleştirerek keskin bir dil ile ayırmaktadır, bu düşünce yaşamın her alanında üretimin ve tüketimin ana malzemesine dönüşmüştür denebilir. Bu nedenle postmodern dönemde erkeğin arzusu, tüketimin arzusu, tüketilme arzusu ve kadının arzusunun kodlamaları beden üzerinde gerçekleşmekte ve bu tavır günlük dilde tüketilen söylemlerin ortak yapısı halini almaktadır. Çünkü Baurdrillard'ın tanımladığı gibi; "Bedenin statüsü bir kültür olgusudur. Hangi kültür olursa olsun bedenle ilişkinin örgütlenme tarzı şeylerle ilişkinin örgütlenme tarzını ve toplumsal ilişkilerin örgütlenme tarzını yansıtır" (Baudrillard, 2007, s. 149). Bu nedenle, nesne olarak algılanan beden, fetiş bir tüketim alanına dönüşmüş ve reklam ile toplumsal üretimin tüm mecralarında bedene anlamlar yüklenmiştir. Baudrillard'a reklam sektöründe beden tanımı burada önem kazanır:

Bin yıllık bir püritanizm çağından sonra fiziksel ve cinsel özgürleşme biçimi altında bedenin 'yeniden keşfi' ve reklamda, modada, kitle kültüründeki (...) mutlak-varlığı- bedenin etrafını kuşatan sağlık, perhiz, tedavi kültü, gençlik, zariflik, erillik/dişilik saplantısı, bedenle ilgili bakımlar, rejimler, fedakârca uygulamalar, bedeni kuşatan Arzu söyleni-, bunların hepsi bedenin günümüzde kurtuluş nesnesine dönüştüğünün tanığıdır. Beden bu ahlaki ve ideolojik işlevde tam anlamıyla ruhun yerini almıştır (Baudrillard, 2007, s. 150).

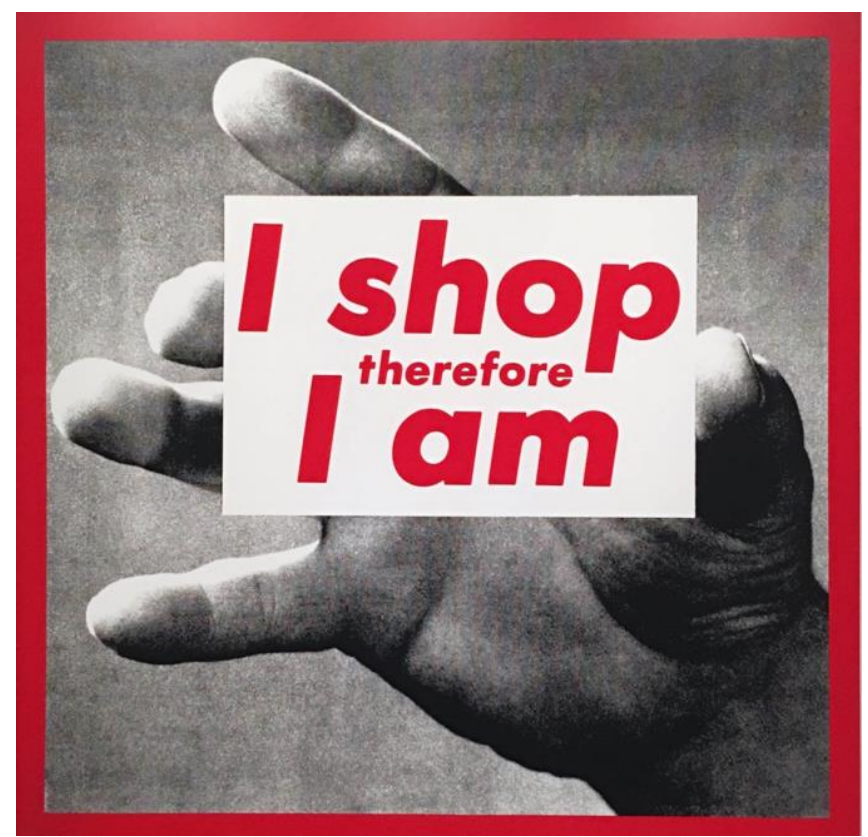

Şekil 3: Barbara Kruger, 1987

I shop therefore I am, (Alışveriş Yapıyorum, Öyleyse Varım)

(Komlik, O., 2015). 
Kruger'in İsimsiz serisinden Şekil 3: I shop therefore I am, (Alışveriş Yapıyorum, Öyleyse Varım) adlı sloganıyla bütünleștirdiği tasarımında, reklamın tüketime olan eleştirisi bulunmaktadır. Kruger'in kırmızı çerçeve ile sinırlandırdığı ve tam ortada bir elin tuttuğu 'alışveriş yapıyorum öyleyse varım' sloganı, kadının ancak tükettiği sürece var olduğu söylemine dokunmaktadır. Bu tasarımda tüketilen sadece meta değildir, aynı zamanda her şeyin satılık olduğu düşüncesine de vurgu yapılmaktadır. Calak'ın da Kruger üzerinden tanımladığı "Kendi imajlarını metalaştırmak için kırmızı çerçeveleri kullanmasından belli olduğu gibi, pazardaki durumlarını ilan etmektedir ve pazarı hiçbir konunun - sanatın en küçüğü kaçınamayacağı reddedilemez koşul olarak işaret etmektedir" (Calak, 2008, s. 3), düşüncesi reklamın ne kadar etkin olduğunun altını kalın çizgilerle çizmektedir. Reklam imajları, Kruger'in afişlerinde hem nesne olarak hem de düşünsel ağının eleştirisi olarak varlık göstermektedir. Çünkü reklam “... "dağıtmadır, herkese ve herkes için karşı1lısız ve sürekli bir sunudur" (Baudrillard, 2007, s. 195). Bu tanım kodlanmış sembolik göstergelerin, toplumsal yapı içerisinde tüketim nesnesi olarak kadın algısı üzerinden biçimlenmesinin kök sebebini açıklamaktadır. Kruger'in afişinde olduğu gibi arzunun yönünü tüketim belirler, o afişlerinde hem kadının anlam olarak tüketimine hem de kadının ihtiyaç olarak tüketimine yönelmektedir. Arzu, çift anlamlılık üzerinde kurgulanarak simgesel bir işlevsellik kazanır, artık kadın tüketmediği sürece varlığından söz edilmediği gibi, tüketilmediği sürece de bir varlık gösterememektedir.

Tüketim bir söylendir. Yani tüketim çağdaş toplumun kendisi üstüne bir söz, toplumumuzun kendisiyle konuşma tarzıdır. Bir anlamda, tüketim toplumunun tek nesnel gerçekliği tüketim fikridir, günlük söylem ve entelektüel söylem tarafindan sürekli yinelenen ve sağduyu gücüne ulaşmış olan bu yansımalı ve söylemsel bileşimidir. Toplumumuz kendini tüketim toplumu olarak düşünür ve konuşur. En azından, bu toplum tükettiği ölçüde kendini tüketim toplumu olarak, fikirde tüketir. Reklam bu fikrin zafer türküsüdür (Baudrillard, 2007, s. 233).

Kruger'in tasarımları, bilinen bir görselin yeniden düzenlenmesi üzerine kurulduğu için reklamın veya üretilmiş afişlerin taklidi olarak algılanmaktadır. Taklit, temsiliyet üzerinde gerçekleşir, temsil ettiği ya bir görüntü ya bir düşünce ya da bir söylem olabileceği gibi, söylemin tersten okuması olarak da görülebilmektedir. Kruger taklit ile, kapitalizmin ortaya çıkardığg tüketim nesnelerinin çoğaltılmış ve yayılmış görsellerini, yeniden üretim yöntemleriyle kendine mal etme hakkı tanıyarak kullanmış, bilinen görüntülere-bilgilere yeni anlamlar ekleyerek tekrar dolaşıma sokmuştur

Sanatın alt-kültürü içinde yer alan bu üretim, pazarlanabilirliği kanıtlanmış medya imgeleri arasından bir resmi alıntılamak ve kendine mal etmekle gerçekleşiyor. Moda ya da basın fotoğraflarından, reklamlardan, filmlerden, televizyondan ve hatta başka sanat yapıtlarından (fotoğraf, resim ya da heykel olsun) alıntılar yapmak, o yapıtın 'özgün' işlevini ve değişim değerini gündeme getirerek, doğal görüntüsünü gerilime sokuyor. Bir imgenin kırpılması, yeniden çekilmesi, bir yerine yazı eklenmesi ve yeniden oluşturulması gibi müdahaleler, imgenin yeterliliğine, özgünlüğüne, müellifine ve mülkiyetine ilişkin soruları gündeme getiriyor (Antmen, 2010, s. 283).

Kruger afişlerinde Ben, Sen, O/Biz, Siz, Onlar zamirlerini kullanarak toplumsal bir hitap dili geliştirmiş̧tir. Düşünmede yer değiştirme ve öteki üzerinde konumlandırma ile ilişkilendirilecek kişisel zamirlerin kullanımı, kimlikleri ikame etme görevini üstlenir ve doğrudan izleyiciye hitap eden bilinçli bir yerleştirmedir. Jameson kişinin kimliği üzerindeki bu yer değiştirmeyi şizofreni kavramı üzerinden açıklarken; Kruger kelimeler ve görüntüler arasındaki çelişkiyi ortaya çıkaracak zamirlerle açıklamaktadır. Böylece modernist kanon söylemlerinin ataerkil yapılanmalarının yerini, postmodern söylenlerde kültürel kimlik olarak anılmakta ve özne sınıflandırılmalarına işaret edebilmektedir. 


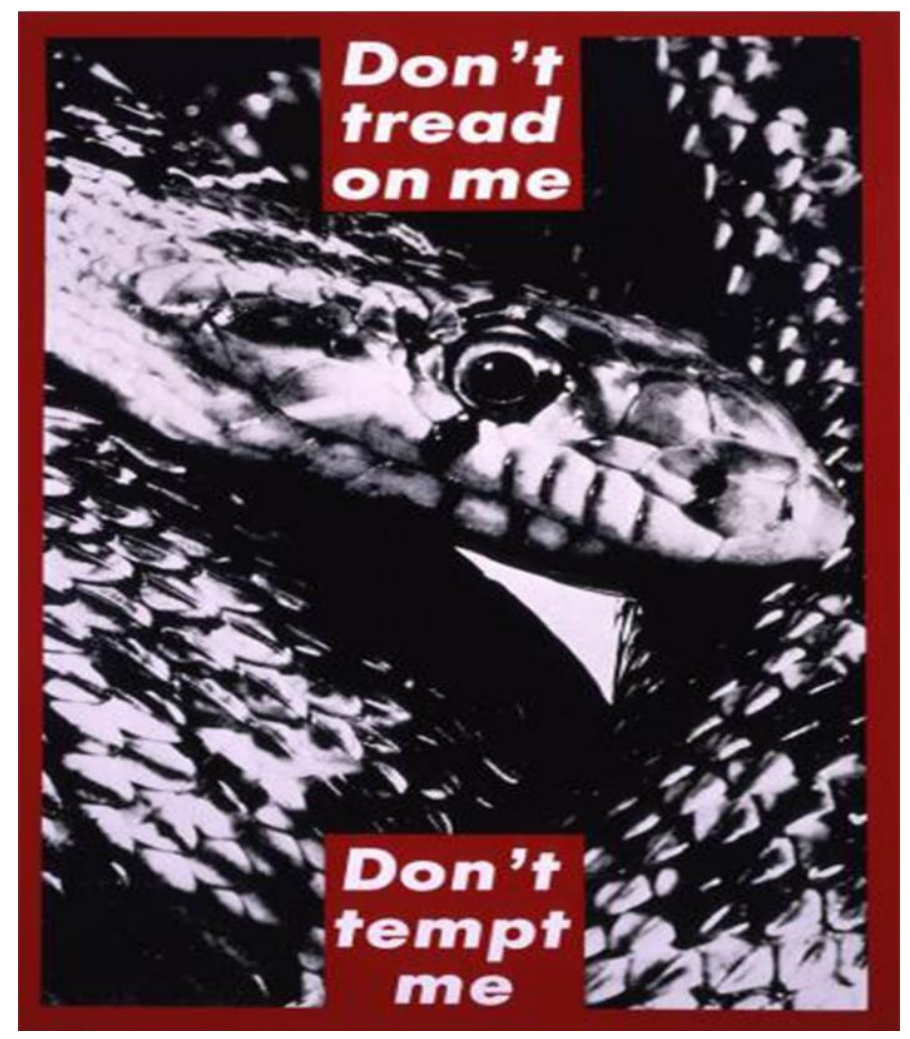

Şekil 4: Barbara Kruger, İsimsiz, 1890-90

Don't tread on me. Don't tempt me

(Üzerime Basma, Beni Ayartma).

(Bailey, B., 2010).

Toplumsal göstergelerin simgeleştirdiği, metin ile görselin çelişkilerini sorgulatan İsimsiz serisinin Şekil 4: Don't tread on me. Don't tempt me (Üzerime Basma, Beni Ayartma) adlı bu afişinde, yılan görüntüsü tüm kültürlerin ortak anlamlandırdığı bir bilgiye işaret etmektedir. Bu bağlamda parodi yöntemi ile açıklanabilecek olan bu tasarımın, 'yılan' görseli ve tam orta eksende kesen kırmızı kutular içerisinde üstte "üzerime basma", alttaki kutudaki metin "beni ayartma" kelimeleri ile ortaya çıkan çifte okuma, eleștirinin odağını olușturmaktadır. İnsanlık tarihinden bu yana kadın ve erkeğin ayartılma baștan çıkarılma metaforu olarak varlık gösteren yılan görseli, kültürün bağlamsal üretiminin değişmezliğini ortaya koymaktadır. Yaratıcılıktan yoksun en bilindik bu görselin anlamı, Sami dinlerinin ilk zamanlarından başlayarak günümüzdeki anlara kadar her toplumda aynı bilgiye işaret etmektedir. Afiş̧ üzerinde metin-slogan rica ve uyarı niteliğiyle eş zamanlı verilerek anlam ikiliği yaratmaktadır. Parodi düzeyinde bu tasarım, klişe olan bir düşüncenin-görüntünün günün koşullarında anlam olarak yüceltilmesi, bir grubun eleştirel dilinin görseli haline gelebilmektedir. Afiş ipek baskı (serigrafi) tekniği ile yaklaşık 12 metre yüksekliğinde vinile basılmıştır. 


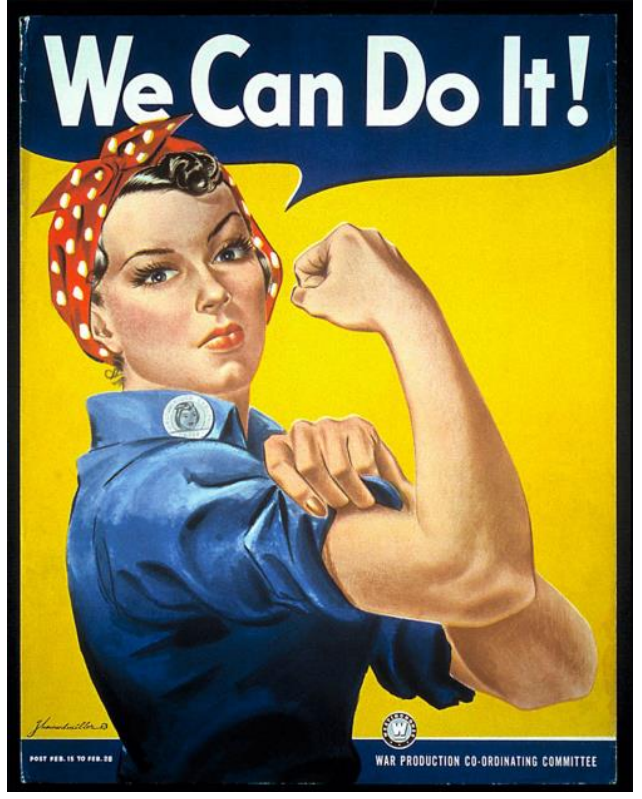

Şekil 5: J. Howard Miller,1943

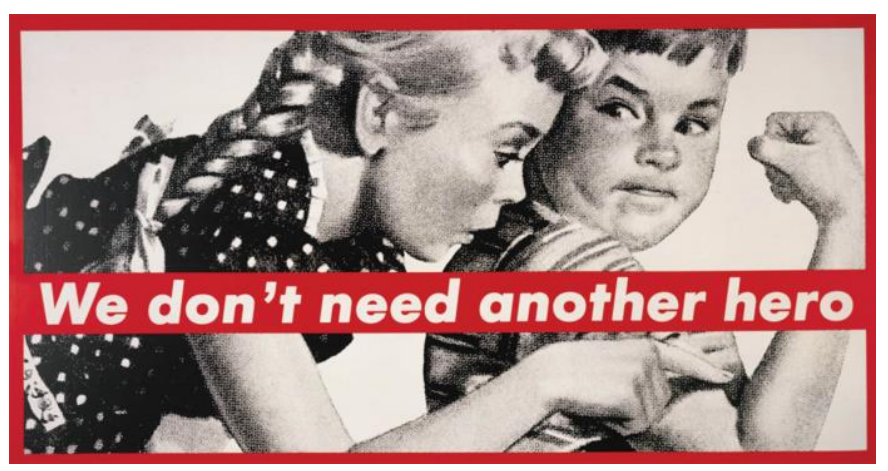

Şekil 6: Barbara Kruger,1987

We don't need another hero

(Başka bir Kahramana ihtiyacımız yok)

(Coovadia, 2017)

1943 yılında J. Howard Miller tarafindan tasarlanan Şekil 5: J. Howard Miller, We can do it, (Yapabiliriz) adlı afiş, Amerikada savaş malzemeleri üreten fabrikada çalışan kadınlardan yola çıkılarak üretilmiş ve feminst kadınların simgesi olarak anlam üretici bir rol üstlenmiştir. Miller'in, (We can do it), bilinen bu afişinin görselini başka bir okumaya dönüştüren Barbara Kruger, Şekil 6: We Don’t Need Another Hero (Başka Bir Kahramana İhtiyacımız Yok) sloganıyla ürettiği afişinde, pastiş gibi algılansa da aslında parodi' dir. Bu afiş savaşın gelecek nesillerin üzerindeki etkisine vurgu yapmaktadır. Parodi ile Kruger Miller'in tasarımını taklit ediyor-muş gibi gözükürken, aslında günün koşullarında göstergelerin anlamının dönüşümünü gözler önüne sermektedir. Nesnenin görüntüsünün altında yatan düşünsel değişimdir ve değişimi günün koşullarındaki, söylemler, gelişmeler, teknoloji gibi unsurlar belirlemektedir. Tüm bu bilgiler bize Kruger'in tasarımlarında siyasetin ve erkek cinselliğinin hâkim olduğu dünyayı yeni bir bakış açısıyla kadın yönüne çevirme arzusunu göstermektedir. Başka bir deyişle Kruger'in tasarımlarında varlık gösteren toplumsal yapılar içerisinde dolanan üretim ve tüketim kavramları, aslında erk hâkimiyetinin kurduğu anlamların yıkımını sağlayacak tek bir yüzey üzerindeki mesaj kodlamaları olarak okunabilir. Böyle bir okuma postmodern kuramların açılımlarıyla gerçekleşebilmektedir. Bu nedenle parodi ve pastiş, postmodern çoklu okumanın önünü açan yöntemler bütünü olarak irdelenebilinir. Her iki yöntem taklit olarak anılsa da hayatın her alanında öznenin parçalanmışlı̆̆ üzerine kurulmuş öteki, sınıf, ırk, cinsiyet, milliyet gibi kavramlara yapışmış anlamları ortadan kaldırma niyetindedir. Bu nedenle yaşam içerisindeki gerçek ve yanılsamayı sorguya açarak dönüştürmektedir. Tüm bu okumaların asıl niyeti, birçok şeyin daha çok önceden düşünülmüş ve söylenmiş olduğunun altını çizmektir. Başka bir deyişle Kruger'in afişlerinde, ataerkil değerlerin toplumsal söylem rollerini irdelemesine olanak tanıyan yeniden üretim yöntemleri, bilginin bilinen anlamının yanına yeni anlamlar eklemlemesinde aracı rolündedir.

\section{Sonuç ve Tartışma}

$\mathrm{Bu}$ metin, Barbara Kruger'in toplumsal güç temsillerini irdelediği isimsiz serisindeki afiş tasarımlarını postmodernizmin argümanları ile okuma niyetiyle kaleme alınmıştır. Bu nedenle Kruger'in isimsiz serisinden beş (5) afiş ile kuram ilişkilendirilmiştir. Barbara Kruger'in hem sanatçı hem de tasarımcı yönü ve basın-yayın mecralarını kullanma ustalığı, bu metin için seçilmesinin ana sebebidir. Onun 
tasarımlarına yüklediği alt metinler, döneminde geniş kitlelere sesini duyurmasında etkin rol üstlenmiştir. Çünkü Kruger' in başarısının ardında toplumca hemfikir olunmuş "bilgi" nin veya "görüntü" nün eleştirel bir dil olarak yeniden üretilmesi fikri yatmaktadır. Bu nedenle Kruger'in tasarımları yeniden üretim dâhilinde postmodern kuramlar ile açıklanabilmektedir. Bu düşünce, Barbara Kruger'in, İsimsiz afiş̧ serileriyle modernist kanon söyleminin kurduğu anlamlandırma edimlerinin hegemonyasının altını deşen alternatif okuma önerilerini destekler niteliktedir. Kruger'in teknik olarak fotoğraf ile güçlü sloganların birlikte harmanlandığı birçok tasarımı bulunmaktadır. O, tasarımlarında tek düze kırmızı çerçeveler, futura yazı karakteri ve sembolleşmiş imajları ortak yapılandırmasına rağmen, sloganları ve görüntüleriyle kurduğu çift kodlama ile anlamı dönüştürecek yeni okumaların ortaya çıkmasını sağlamıştır. Kruger afişlerinde yapılandırdığı zamirleriyle ötekini inşa etmiş ve bilindik görüntülersöylemlerle sabitlenmiş anlamları manipüle etmiştir. Postmodern dönem temel konuları, kültürel kimlik, güç, iktidar, cinsellik ve ayrışmaların sorgulanma sürecinde tekrarlar, var olan sanat yapıtlarının yeniden yorumlanması, yeniden üretme ve dönüştürme dâhilinde gerçekleşmektedir. Geçmiş ve şimdiki zaman kaymaları arasında gerçekleşen eleştirel bir düşünce biçimde varlık gösteren yeniden üretim tanımları; sanatın, tasarımın, hayatın kopyalama ve çoğaltılabilme özelliklerine vurgu yaparak, düşüncenin zamansal orijinalliğini de sorgulamaktadır. Bu durum sanatçı-tasarımcıya anlama başka bir çerçeveden bakma hakkını da tanımaktadır. Böylece sanatçı-tasarımcı yeniden üretim yöntemleriyle kamuya mal olmuş sanat yapıtlarını veya görsel materyalleri olduğu gibi değiştirmeden kullanılabildikleri gibi, görsellerin nitelikleriyle oynayarak yeni anlamlar eklemleyebilmiştir. Bu düşünce kopya sanat eserlerinin değerinin tartışma konusu yaparken, bir yanda da sanat nesnesine yüklenen tek anlamın yıkılması olarak da okunabilmektedir. Bazı sanat eleştirmenlerince yeniden üretim yöntemlerini, sanat-tasarım eserlerinin konumunu daraltmak olarak görse de, aslında bu konuyla ilgili tartışmaları genişletmek olduğu ve sanatın-tasarımın düşünsel açılımlarının geliştirilmesine ivme kazandıracağı da varsayılabilir. Belki de bu alıntılama tekniklerini ürettiği yeni okuma biçimleri, atıfta bulunduğu kült sanatın üreticisine saygınlığı olarak da nitelenebilir. Diğer yandan görsel sanatlarda bir şok etkisi yaratan bir alt-üst metin okuması, aslında bitemeyen bir döngünün dönüşümünü de gözler önüne de sermektedir. Bu nedenle yeniden üretim yöntemleriyle Kruger'in tasarımların bakmak, hem bitmeyen tamamlanmayacak sonsuz bir okuma sürecine işaret etmekte, hem de tasarımda yöntembilimin önemini açıklayan yeni bir okuma olması bağlamında önemlidir. Çünkü grafik tasarım, toplumsal bilgi koşullarının değişimini sorgulayan, anlamlandıran ve günün koşullarında yeniden üretim fikrini görselleşmesini sağlayan en yaygın kullanılan alandır. Her tasarım fikrinin kökeninde bilgi vardır. Ancak bu düşünceyle çözümlenen bir tasarım, farklı zaman ve mekânda daha önce söylenmiş olanın yeniden üretilerek anlamlanabileceği bilgisi üzerinde barınabilecektir. Böyle sonsuz bir döngüde devinen bilgi, ancak parodi ve pastiş gibi yöntemlerle, içeriğine yapışmış tanımlardan göstergeyi kurtarabilmekte, bitmemişlik ve süreksizlik duygusu ile yeni okumalara izin verebilmektedir.

\section{KAYNAKÇA}

Aktulum, K. (2007). Metinlerarast ilişkiler. İstanbul: Öteki Yayınevi.

Aktulum, K. (2011). Metinlerarasıllk // göstergelerarasıllk. Ankara: Kanguru Yayınları.

Antmen, A. (2010). Sanatçılardan yazılar ve açıklamalarla 20. Yüzyil Batı sanatında akımlar. İstanbul: Sel Yayıncilik.

Baudrillard, J. (2007). Tüketim toplumu. (çev. Hazal Deliceçaylı, Ferda Keskin). İstanbul: Ayrıntı Yayınları.

Benjamin, W. (2012). Pasajlar. (çev. Ahmet Cemal). İstanbul: YKY.

Berger, John. (1986). Görme biçimleri. (çev. Yurdanur Salman). İstanbul: Metis Yayıncıllk

Bourdieu, P. (2015). Eril tahakküm. (çev. Bediz Yılmaz). İstanbul: Bağlam Yayıncılık. 
Calak, K. (2008). Barbara Kruger, your body is a battleground. 10 Kasim 2015 tarihinde Http://Citeseerx.İst.Psu.Edu/Viewdoc/Download?Doi=10.1.1.617.2506\&Rep=Rep1\&Type=Pd $\mathrm{f}$ adresinden erişildi.

Goodchild, P. (1996). Deleuze \& Guattari arzu politikasına giriş. (çev: Rahmi G. Öğdül). İstanbul: Ayrıntı Yayınları

Jameson, F. (2005). Kültürel dönemeç. (çev. Kemal İnal). Ankara: Dost Kitabevi.

Rose, M. A. (2016). Parodi: antik, modern ve postmodern. (çev. Cansu Dikme). Ankara: Hece Yayınları.

sanagrafi.com. (2012). 11 Şubat 2018 tarihinde https://www.sanagrafi.com/futura-yazi-karakteri adresinden erişildi.

Sarup, M. (2010). Postyapısalcllık ve postmodernizm eleştirel bir giriş. (çev: Abdülbaki Güçlü). İstanbul: Kırkgece Yayınlar1.

Steven Heller, V. V. (2016). Grafik tasarımı değiştiren 100 fikir. (çev: Bengisu Bayrak). İstanbul: Litaratür Yayınc1lik.

Şahiner, R. (2008). Sanatta postmodern kirılmalar ya da modernin yapıbozumu. İstanbul: İnsan Yayınevi.

Türk Dil Kurumu. (2011). Güncel Türkçe sözlük. Ankara: TDK Yayınları. 9 Mayıs 2018 tarihinde http://sozluk.gov.tr/ adresinden erişildi.

\section{GÖRSEL KAYNAKLAR}

Bailey, B. (2010). Spotlight talk: Barbara Kruger's untitled. 1 Nisan 2019 tarihinde https://samfoxschool.wustl.edu/events/gallery-talks/4536 adresinden erişildi.

Caldwell, E. C. (2016). The history of your body is a battleground. 1 Mart 2018 tarihinde https://daily.jstor.org/the-history-your-body-is-a-battleground adresinden erişildi.

Coovadia, A. (2017). We don't need another hero' by Barbara Kruger postmodern features explained. 1 Mayıs 2018 tarihinde https://medium.com/@aaliacoovadia/postmodern-features-explainedthrough-we-dont-need-another-hero-by-barbara-kruger-b7a1668fc683 adresinden erişildi.

Garber, M. (2015). The many faces of rosie the riveter, why there are so many women who claim to have been the inspiration for the iconic we can do it! 1 Ağustos 2019 tarihinde https://www.theatlantic.com/entertainment/archive/2015/04/the-many-faces-of-rosie-theriveter/391364/ adresinden erişildi.

Hedonia, A. (2019). 1 Agustos 2019 tarihinde https://feministartpower.files.wordpress.com/2012/09/ yourgaze_barbarakruger-01.jpg adresinden erişildi.

Komlik, O. (2015). Economic sociology and political economy, I shop therefore I am. 1 May1s 2019 tarihinde https://economicsociology.org/2015/08/01/i-shop-therefore-i-am/ adresinden erişildi. 